Proc. 194th Electrochemical Society Meeting, Volume on Selected

Battery Topics, Boston, Nov. 1-6, 1998 .

BNL -66600

\title{
REACTION KINETICS AND X-RAY ABSORPTION SPECTROSCOPY STUDIES OF YTTRIUM CONTAINING METAL HYDRIDE ELECTRODES
}

$$
\text { CONF-98/108- - }
$$

E. A. Ticianelli, S. Mukerjee, J. McBreen, G. D. Adzic, J. R. Johnson, and J. J. Reilly

Department of Applied Science.

Brookhaven National Laboratory, Upton, NY 11973.

\section{ABSTRACT} JUL 211999

This was a study of electrode degradation mechanisms and the reaction kinetics 9 S I $\mathrm{LaNi}_{4.7} \mathrm{Sn}_{0.3}, \mathrm{La}_{(1-\mathrm{x})} \mathrm{Y}_{\mathrm{x}} \mathrm{Ni}_{4.7} \mathrm{Sn}_{0.3}(\mathrm{x}=0.1,0.2$, and 0.3$)$ and $\mathrm{La}_{0.7} \mathrm{Y}_{0.3} \mathrm{Ni}_{4.6} \mathrm{Sn}_{0.3} \mathrm{Co}_{0.1}$ metal hydride electrodes. Alloy characterization included $\mathrm{x}$-ray diffraction (XRD), $\mathrm{x}$-ray absorption (XAS), hydrogen absorption in a Sieverts apparatus, and electrochemical cycling of alloy electrodes. The atomic volume of $\mathrm{H}$ was determined for two of the alloys. Electrochemical kinetic measurements were made using steady state galvanostatic measurements, galvanodynamic sweep, and electrochemical impedance techniques. XAS was used to examine the degree of corrosion of the alloys with cycling. Alloying with $Y$ decreased the corrosion rate. The results are consistent with corrosion inhibition by a $Y$ containing passive film. The increase in the kinetics of the hydrogen oxidation reaction (HOR) with increasing depth of discharge was much greater on the $Y$ containing alloys. This may be due to the dehydriding of the catalytic species on the surface of the metal hydride particles.

\section{INTRODUCTION}

Previous studies have shown that $\mathrm{LaNi}_{5}$ alloy modifications affect the cycle life and hydrogen absorption capacity of the electrode, but sometimes the reasons for these effects are not well understood [1-6]. In commercial $\mathrm{AB}_{5}$ electrodes, pure $\mathrm{La}$ is substituted by mischmetal $(\mathrm{Mm})$, a naturally occurring mixture of the rare earth metals, corresponding mainly to (in atom percent, a/o): $50-55 \mathrm{Ce}, 18-28 \mathrm{La}, 12-18 \mathrm{Nd}$, and 4-6 $\mathrm{Pr}$ [7]. A typical composition for use in batteries is $\mathrm{MmNi}_{3.5} \mathrm{Co}_{0.75} \mathrm{Mn}_{0.4} \mathrm{Al}_{0.3}$ [8]. Apart from $\mathrm{La}, \mathrm{Ce}$ is the predominant rare earth in normal $\mathrm{Mm}$, so the role of Ce has been investigated in some detail $[7,9]$. Results indicate an improvement in the cycle life due to the presence of $\mathrm{Ce}$, and this effect has been attributed to the formation of a passivating $\mathrm{Ce}$ oxide $[9,10]$.

Our recent studies show that XAS is a very useful technique for the study of alloy hydrides and particularly the role of the electronic structure, the environment around minor constituents, and the corrosion of individual components in the alloy [7,9-11].

The effect of $\mathrm{La}$ or $\mathrm{Ni}$ substituents on the kinetics of the hydrogen oxidation reaction and the absorption process, has not been investigated in a systematic way. Most kinetic studies used transient and steady state polarization techniques [12-19], and electrochemical impedance spectroscopy [20-28].

This work was a study of the effect of $\mathrm{Y}$ as a substituent for La on the cycle life and charge/discharge reaction kinetics. The alloys included $\mathrm{LaNi}_{4.7} \mathrm{Sn}_{0.3}, \mathrm{La}_{(1-\mathrm{x})} \mathrm{Y}_{\mathrm{x}} \mathrm{Ni}_{4.7} \mathrm{Sn}_{0.3}$ 
( $x=0.1,0.2$, and 0.3 ), and $\mathrm{La}_{0.7} \mathrm{Y}_{0.3} \mathrm{Ni}_{4.6} \mathrm{Sn}_{0.3} \mathrm{Co}_{0.1}$. Studies included measurements of charge/discharge characteristics, cycle life studies, galvanodynamic potential vs. current profiles, and electrochemical impedance spectra (EIS) at several states of charge and at several temperatures. XAS was used to characterize the corrosion products in cycled electrodes.

\section{EXPERIMENTAL}

\section{Alloy preparation and characterization}

All the alloys were prepared from high purity ( $>99.9 \%)$ starting materials by an arc melting technique followed by an annealing step at a temperature of $1173 \mathrm{~K}$ for $48 \mathrm{~h}$. XRD patterns were obtained for each alloy, and their lattice parameters determined. The molar volume of hydrogen in the hydride phase was also determined. Details of these procedures are given elsewhere [7].

\section{Cycling and electrochemical studies}

The alloys were first activated by subjecting each to several hydriding/dehydriding cycles in a Sieverts apparatus. Electrodes were prepared by pressing a mix comprised of $0.1 \mathrm{~g}$ of the alloy powder, $0.1 \mathrm{~g}$ carbon black (Monarch 2000), and 33 weight percent (w/o) polytetrafluoroethylene (PTFE) binder (Teflon T30), on both sides of a 80 mesh nickel screen disc with a geometric area of $2.0 \mathrm{~cm}^{2}$. Electrochemical measurements were done in a three electrode cell, in $6 \mathrm{M} \mathrm{KOH}$, with a Pt mesh counter electrode, and a $\mathrm{Hg} / \mathrm{HgO}$ reference electrode.

Life cycle tests were done by charging at ca. a $\mathrm{C} / 3$ rate $(10 \mathrm{~mA})$ for $4 \mathrm{~h}$ and discharging at the same rate to a cutoff cell potential of $0.7 \mathrm{~V}$ vs. $\mathrm{Hg} / \mathrm{HgO}$. The electrochemical impedance spectra (EIS) were obtained in the frequency range of $10 \mathrm{kHz}$ to $1 \mathrm{mHz}$, with an ac amplitude of $5 \mathrm{mV}$, with the electrodes maintained at the open circuit potential. Galvanodynamic potential vs. current profiles (GYP) were obtained for the electrodes at several states of charge (SOC) with the cell thermostated at 10, 25, 40 and $55^{\circ} \mathrm{C}$, using a Solartron potentiostat. GYP profiles were recorded at a scan rate of $0.01 \mathrm{~mA} \mathrm{~s}^{-1}$ for currents varying within $\pm 1.5 \mathrm{~mA}$.

\section{$\underline{X-r a y ~ a b s o r p t i o n ~ s p e c t r o s c o p y ~}$}

XAS measurements were made on both uncycled and cycled alloy powders. After cycling the electrode material was removed from the current collector, washed with deionized water to remove $\mathrm{KOH}$ and ultrasonically dispersed in acetone. After drying, the disc pellet for XAS analysis was prepared by pressing these materials on the top of a PTFE-bonded porous carbon substrate (ETEK).

The XAS at the Ni K edge were done in both the transmission and electron yield modes. In the transmission mode, results are more sensitive to properties of $\mathrm{Ni}$ atoms in bulk alloy. According to a previous calculation [10], using a method described in the literature [29], at the energy of the $\mathrm{Ni} \mathrm{K}$ edge, the electron yield measurements provide 


\section{DISCLAIMER}

This report was prepared as an account of work sponsored by an agency of the United States Government. Neither the United States Government nor any agency thereof, nor any of their employees, make any warranty, express or implied, or assumes any legal hability or responsibility for the accuracy, completeness, or usefulness of any information, apparatus, product, or process disclosed, or represents that its use would not infringe privately owned rights. Reference herein to any specific commercial product, process, or service by trade name, trademark, manufacturer, or otherwise does not necessarily constitute or imply its endorsement, recommendation, or favoring by the United States Government or any agency thereof. The views and opinions of authors expressed herein do not necessarily state or reflect those of the United States Government or any agency thereof. 


\section{DISCLAIMER}

Portions of this document may be illegible in electronic image products. Images are produced from the best available original document. 
surface sensitive XAS of the alloy particles to a depth of ca. 200-250 A. XAS at the Y K edge were done in the transmission mode. The XAS data analysis was done according to procedures described in detail elsewhere [30-32].

\section{RESULTS AND DISCUSSION}

\section{Electrode capacity, steady state kinetics and capacity decay}

Figure 1 shows typical discharge profiles obtained for the $\mathrm{LaB}_{5}$ and $\mathrm{La}_{0.8} \mathrm{Y}_{0.2} \mathrm{~B}_{5}$ alloys $\left(\mathrm{B}_{5}=\mathrm{Ni}_{4.7} \mathrm{Sn}_{0.3}\right)$ after 1, 5,10,15 and 20 charge/discharge cycles. Table 1 shows the values of the maximum discharge capacity obtained for each alloy, together with their capacity decay rates with cycling. Also included, for two alloys $\left(\mathrm{LaB}_{5}\right.$ and $\left.\mathrm{La}_{0.8} \mathrm{Y}_{0.2} \mathrm{~B}_{5}\right)$, are the atomic volume of $\mathrm{H}$ in the hydride phase, the number of $\mathrm{H}$ per unit cell, and the expansion of unit cell due to charging. Plots of the discharge capacity normalized with respect to the maximum capacity are presented in Fig. 2 for the alloys containing $0,0.1$ and 0.2 atomic fraction (x) of $\mathrm{Y}$ with respect to the total amount of $\mathrm{Y}$ and La.

Results in Fig. 1 show that from cycle 1 to 20 the capacity first increases with cycle number and then reaches a maximum for both alloys, and thereafter decreases with cycling due to corrosion of the alloy. The number of cycles required for alloy activation was dependent on the composition, and increased with higher yttrium content.

The sample with $\mathrm{x}=0.2$ exhibited the highest stability (i.e lowest rate of capacity loss) whereas the alloy with $\mathrm{x}=0$ (no $\mathrm{Y}$ ) had the largest capacity decay (Table 1). There was no apparent direct correlation between the capacity decay and the volume changes occurring in the alloys during cycling. The maximum value of discharge capacity generally decreases with increasing $Y$ content in the alloy. According to the experimental capacity vs. cycle curves (Fig. 2) and the data in Table 1, at 100 cycles the alloys with $\mathrm{x}=$ 0.2 and with $\mathrm{x}=0$ have the same capacity $\left(240 \mathrm{mAh} \mathrm{g}^{-1}\right)$, and with further cycling the former shows superior performance. At 300 cycles the respective capacities for $\mathrm{LaNi}_{4.7} \mathrm{Sn}_{0.3}$ and $\mathrm{La}_{0.8} \mathrm{Y}_{0.2} \mathrm{Ni}_{4.7} \mathrm{Sn}_{0.3}$ are 100 and $200 \mathrm{mAh} \mathrm{g}$, indicating a considerable improvement of cycling stability promoted by $\mathrm{Y}$.

The results in Fig. 1 show an increase in the electrode discharge potential during the activation process. In the sample with $\mathrm{Y}$, there was a clear increase in electrode potential with increasing depth of discharge. This indicates that the overall kinetics of the hydrogen oxidation reaction (HOR) changes with the depth of discharge, with $Y$ playing an important role,

\section{Galvanodynamic and EIS studies}

Figure 3 presents examples of the gavanodynamic discharging profiles obtained at $25{ }^{\circ} \mathrm{C}$ with the electrodes at a $100 \%$ state of charge. To avoid polarization effects related to hydrogen atom transport processes in the galvanodynamic method, the reaction kinetics was studied in a very low current density range. For these conditions the polarization of the electrode can be treated assuming that the charge transfer step in the 
charge/discharge mechanism (where $\mathrm{S}$ is an active site at the alloy surface) is the rate determining step. [28]. The overall mechanism is:

$$
\begin{array}{ll}
\mathrm{H}_{2} \mathrm{O}+\mathrm{S}+e^{-} \Leftrightarrow S-H_{a d s}+O H^{-} & \text {(charge transfer) } \\
S-H_{a d s} \Leftrightarrow S-H_{a b s(\text { surface })} & \text { (absorption) } \\
S-H_{a b s(\text { surface })} \Leftrightarrow S-H_{a b s(b u l k)} & \text { (diffusion) } \\
S-H_{a b s(b u l k, \alpha)} \Leftrightarrow S-H_{a b s(b u l k, \beta)} & \text { (phase transition) }
\end{array}
$$

Also, for these conditions the catalytic activity can be measured by the value of the exchange current density $\left(j_{o}\right)$ which can be obtained from the slope of the polarization curves $(j$ vs. $\eta)$ at low reaction overpotential $(\eta)$ using the equation

$$
j_{o}=\frac{R T}{F}\left(\frac{j}{\eta}\right)_{\eta \rightarrow 0}
$$

where $\mathrm{F}$ is the Faraday constant, $\mathrm{R}$ is the gas constant and $\mathrm{T}$ is the temperature. Values of $j_{o}$ were obtained for activated and cycled metal hydride alloys at $100 \%$ SOC (state of charge) and some representative results are summarized in Table 2. The activation energy, obtained from Arrhenius plots $\left(\log j_{o}\right.$ vs $\left.1 / \mathrm{T}\right)$, are also presented in Table 2.

Figures 4 and 5 show the impedance plots of activated $\mathrm{LaNi}_{4.7} \mathrm{Sn}_{0.3}$ and $\mathrm{La}_{0.8} \mathrm{Y}_{0.2} \mathrm{Ni}_{4.7} \mathrm{Sn}_{0.3}$ alloy electrodes (4 cycles and 20 cycles, respectively) in the form of Nyquist or Cole-Cole plots at several states of charge (SOC) at 25 and $40^{\circ} \mathrm{C}$. In Figure 6 , data at 10 and $25^{\circ} \mathrm{C}$ were plotted expanding the region of high frequency for the activated $\mathrm{La}_{0.8} \mathrm{Y}_{0.2} \mathrm{Ni}_{4.7} \mathrm{Sn}_{0.3}$ alloy electrode to highlight the impedance features in this region. Figure 7 presents the results obtained at several temperatures for the activated and fully charged $\mathrm{La}_{0.8} \mathrm{Y}_{0.2} \mathrm{Ni}_{4.7} \mathrm{Sn}_{0.3}$ hydride electrode.

For both electrodes at the several SOC's and temperatures, it is observed that in the high frequency range that the impedance spectra show an arc coupled to an apparent linear region. In the lower frequency region another arc is seen which depends on the temperature and the state of charge and is coupled to another feature related to a moderate or a steep increase of the imaginary component of the impedance. It should be noted that these impedance responses are similar to results presented for many other metal hydride alloys [20-28]. Interpretation of these features has been a matter of controversy. Zhang et al [21] assigned the arc in the higher frequency region (from $20 \mathrm{kHz}$ to $520 \mathrm{~Hz}$ ) to the impedance between the current collector and the active material, the features at the middle frequency range (from 130 to $12 \mathrm{~Hz}$ ) to the particle to particle electronic conductance of the MH electrodes, and the arc at low frequency (from $10 \mathrm{~Hz}$ to $10 \mathrm{mHz}$ ) to the charge transfer step at the electrode/electrolyte interface. However, more recently, based on ac modeling of the kinetics of metal hydride electrodes, Wang [28] attributed these three features, seen at decreasing frequencies, to the charge transfer reaction, surface absorption, and hydrogen diffusion, as represented by reactions (1), (2), and (3) above. Based on previous work [20-28] and the present results, the following assignments are proposed for the observed impedance features: 
Arc in the range of $8 \mathrm{kHz}$ to $200 \mathrm{~Hz}$ : Figs. 6 and 7 (b) show that the magnitude of the high frequency arc varies only slightly with temperature and cannot be assigned to either the charge transfer step [28] or to the diffusion of hydrogen. The results are consistent with a contact resistance between the current collector and the active material, as originally proposed by Zhang et al [21].

(ii) Features in the range of ca. 200 to ca. $2 \mathrm{~Hz}$ : From the results of Fig. 6 and 7 (b) it is clear that this feature appears as a linear region, the extent of which is dependent on the SOC and on the temperature. It is most likely related to the diffusion processes taking place inside the $\mathrm{MH}$ particles, as proposed by Wang [28]. However, the assignment by Zhang et al [21] to particle to particle electronic conductance of the $\mathrm{MH}$ electrodes is also plausible.

(iii) Arc in the range of $2 \mathrm{~Hz}$ to $10 \mathrm{mHz}$ : The magnitude and the characteristic frequency of this feature is dependent on the alloy composition, the state of charge and the temperature (Figs. 4 and 5). In accordance with what has been proposed for most metal hydrides [20-27], this feature is associated with the charge transfer step at the electrode/electrolyte interface.

The charge transfer resistance $\left(R_{c t}\right)$ at the electrode electrolyte interface is given by $(\eta / j)$ and the ac measurements were made for $\eta \cong 0$, so that equation (5) can also be used to obtain the exchange current density of the HOR from $R_{c t}$ data. Table 3 presents these values for the activated $\mathrm{LaNi}_{4.7} \mathrm{Sn}_{0.3}$ and $\mathrm{La}_{0.8} \mathrm{Y}_{0.2} \mathrm{Ni}_{4.7} \mathrm{Sn}_{0.3}$ alloys at several $\mathrm{SOC}$ at $25^{\circ} \mathrm{C}$. The kinetic data obtained from impedance measurements (Table 3 ) are consistent with those obtained from the galvanodynamic experiments (Table 2)

Table 2 shows that presence of $Y$, in any amount, decreases the exchange current density $\left(j_{o}\right)$ for the charge/discharge processes. However, within the experimental error, the activation energies are essentially the same in the presence or absence of $Y$. From these results it is concluded that the differences in the charge/discharge reaction kinetics are merely a consequence of the different surface area of the alloys. When the electrodes with $\mathrm{x}=0$ and $\mathrm{x}=0.2$ were cycled 130 times, there was an increase of $j_{o}$, an effect that is associated with the increase of surface area with cycling.

Table 3 shows that the exchange current density for $\mathrm{La}_{0.8} \mathrm{Y}_{0.2} \mathrm{Ni}_{4.7} \mathrm{Sn}_{0.3}$ increases with decreasing state of charge, while the activation energy remains relatively constant. In the case of $\mathrm{LaNi}_{4.7} \mathrm{Sn}_{0.3}$ the increase in $j_{O}$ with depth of discharge was much less. This behavior of $j_{o}$ is consistent with the results of Fig. 1, where the increase in the electrode potential as a function of discharge time was much more obvious for the sample with Y. An increase of $j_{o}$ with the decrease of SOC has been also reported for several other metal hydrides $[20,22,25,27]$. In alkaline water electrolyzers is well known that the kinetics of hydrogen evolution on the nickel cathodes decreases with time. This has been attributed to hydriding of the nickel [28]. A similar mechanism may be occurring here on the metallic surface species responsible for the catalytic surface processes. Dehydriding of these species, with decreasing SOC, increases the kinetics of the HOR. 


\section{$\underline{\text { XAS studies }}$}

Figures 8 and 9 present representative XANES results in the transmission and electron yield modes at the Ni $\mathrm{K}$ edge for uncycled metal hydride alloys. From the results in the transmission mode (Fig. 8) it is seen that, compared with Ni, the shoulder centered at $0.0 \mathrm{eV}$ is higher for the metal hydride alloys and the edge position is shifted by ca. $2.0 \mathrm{eV}$ below that found for Ni. No apparent effect is introduced by replacement of La by Y or of Ni by Co. In the case of the electron yield mode (Fig. 9) the edge shift is somewhat smaller than in the transmission mode and the pre edge shoulder centered at $0.0 \mathrm{eV}$ has essentially the same magnitude as for pure $\mathrm{Ni}$.

The data obtained in the transmission mode give information on bulk properties whereas those for the electron yield are more surface sensitive. In the transmission mode the intensity of the pre-edge shoulder is higher than in the electron yield mode, so the properties of the $\mathrm{Ni}$ atoms in the bulk of the alloy particles must be somewhat different than those on the surface, with the latter having a smaller overlap of $p$-d orbitals and/or a smaller number of empty $d$ states. The Ni XANES is the same in the presence or absence of $\mathrm{Y}$ (for both transmission and electron yield modes), indicating that the electronic structure of the alloy is very little affected when $\mathrm{La}$ is replaced by $\mathrm{Y}$. This is why the HOR kinetics is not affected by the presence of $Y$, as seen in Table 2 .

Figures 10 to 11 compare the XANES spectra obtained at the Ni $\mathrm{K}$ edge in the transmission and electron yield modes, respectively, for uncycled and cycled (100 times) dehydrided electrodes. Figure 12 presents the results obtained in the electron yield mode, after 300 cycles. The spectra in the transmission mode (Fig. 10) for the uncycled and cycled electrodes are similar, except for a small reduction in the magnitude of the preedge shoulder for the cycled samples, especially for the alloy without $Y$. Besides the preedge effect, spectra in the electron yield mode for the cycled samples (Fig. $11-100$ cycles and Fig. 12 - 300 cycles) have an enhanced white line which is absent in uncycled samples. Comparison of results if Figs. 11 and 12 clearly shows that there is an increase in the while line magnitude with cycling. Since the corrosion product is accumulated on the particle surface, its presence is more apparent from measurements in the electron yield spectra, as clearly confirmed by comparison of the results in Figs. 10 and 11. There is a clear reduction in the white line (Figs. 11 and 12) as the $\mathrm{Y}$ content is increased, indicating reduction in Ni corrosion introduced by $\mathrm{Y}$. This is the reason for the improved lifetime of the $\mathrm{Y}$ containing metal hydride alloys.

XANES spectra, at the $\mathrm{Y} \mathrm{K}$ edge, for uncycled and cycled (100 times) $\mathrm{La}_{0,7} \mathrm{Y}_{0.3} \mathrm{Ni}_{4,7} \mathrm{Sn}_{0,3}$ are presented in Figure 13. As in the case of Ni, the XANES at the Y K edge for uncycled and activated samples were similar (not shown); also, the results for samples cycled up to 300 times (not shown) were essentially the same as that for 100 cycles. The spectrum of $Y$ in the unclycled alloy is similar to that of the bulk metal. The samples cycled 100 times show an enhanced white line that is approximately the same as for a sample cycled 300 times. As in the case of $\mathrm{Ni}$, this behavior can be attributed to the formation of $\mathrm{Y}$ hydrous oxides upon cycling. However, as opposed to $\mathrm{Ni}$, the amount of $\mathrm{Y}$ hydrous oxides remains essentially constant after ca. 100 cycles which is consistent 
with formation of a finite surface layer of the product with no further buildup beyond 100 cycles.

The alloys with $\mathrm{Y}$ have a lower exchange current, or equivalently a smaller surface area than in the absence of $Y$. Table 2 shows that the ratio of increase of the exchange current density (Table 2) with cycling is similar for the samples with and without $\mathrm{Y}$, indicating a proportional enlargement of the alloy surface area as cycling progresses. Therefore, the protection of $Y$ cannot be ascribed to less pulverization of the alloy on cycling. Also, the rate of capacity decay in Table 1 shows no direct relationship to the exchange current density, and therefore no relationship with the alloy surface area, indicating that the protecting mechanism is not related to the surface area or the particle size It must be concluded then that the corrosion protection mechanism must be associated with the presence of a physical barrier of $\mathrm{Y}$ hydrous oxide which acts as a blocking passivating layer.

\section{ACKNOWLEDGMENTS}

The authors acknowledge the support of the U.S. Department of Energy under Contract No. IE -AC02-98CH10886. E. A. T. is on leave of absence from Instituto de Química de São Carlos/USP, Brazil, with a scholarship from Fundação de Amparo a Pesquisa do Estado de São Paulo (FAPESP).

\section{REFERENCES}

1. B. V. Ratnakumar, C. Witham, R. C. Bowman Jr., A. Hightower, and B. Fultz, J. Electrochem. Soc., 143 (1996) 2578, and references citted therein.

2. G. D. Adzic, J. R. Johnson, S. Mukerjee, J. McBreen, and J. J. Reilly, J. Alloys and Compounds, 253-254, 579 (1997).

3. B. V. Ratnakumar, G. Halpert, C. Witham, and B. Fultz, J. Electrochem. Soc., 141, (1994) 189.

4. B. V. Ratnakumar, S. Surampudi, S. Di Stefano, G. Halpert, C. Witham, A. Hightower, and B. Fultz, in Hydrogen and Metal Hydride Batteries, P. D. Bennett and T. Sakai, Eds., PV94-27, p. 57. The Electrochemical Society Proceedings Series, Pennington, NJ (1994).

5. C. K. Witham, R. C. Browman Jr., B. V. Ratnakumar, B. Fultz, and S. Surampudi, Proceeding of 1996 IEEE, 129 (1996).

6. C. Witham, B. V. Ratnakumar, R. C. Bowman Jr., A. Hightower, and B. Fultz, J. Electrochem. Soc., 143, L206 (1996).

7. G. D. Adzic, J. R. Johnson, J. J. Reilly, J. McBreen, S. Mukerjee, M. P. S. Kumar, W. Zang, and S. Srinivasan, J. Electrochem. Soc., 142, 3429 (1995).

8. M. E. Fiorino, R. L. Opila, K. Konstadinidas, and W. C. Fang, J. Electrochem. Soc., $143,2422(1996)$.

9. S. Mukerjee, J. McBreen, J. J. Reilly, J. R. Johnson, G. Adzic, K. Petrov, M. P. S. Kumar, W. Zang, and S. Srinivasan, J. Electrochem. Soc., 142 (1995) 2278.

10. S. Mukerjee, J. McBreen, J. J. Reilly, J. R. Johnson, and G. D. Adzic in Batteries for Portable Applications and Electric Vehicles, C. F. Holmes and A. R. Landgrebe, 
Editors, PV 97-18, The Electrochemical Society Proceedings Series, Pennington, NJ (1997).

11. S. Srinivasan, W. Zang, M. P. S. Kumar, A. Visintin, S. Mukerjee, J. McBreen, G. Adzic, J. R. Johnson, J. J. Reilly, R. B. Schwarz, M. L. Wasz and H. S. Lim, J. Electrochem. Soc., in press.

12. A. Zuttel F. Meli, and L. Schlapbach, J. Alloys and Compounds, 221, 207 (1995).

13. Q. M. Yang, M. Ciureanu, D. H. Ryan, and J. O. Strom-Olsen, J. Electrochem. Soc., 141, 2108 (1994).

14. Q. M. Yang, M. Ciureanu, D. H. Ryan, and J. O. Strom-Olsen, J. Electrochem. Soc., 141, 2113 (1994).

15. G. Zheng, B. N. Popov, and R. E. White, J. Electrochem. Soc., 142, 2695 (1995).

16. Y. Fukumoto, M. Miyamoto, M. Matsuoka, and C. Iwakura, Electrochim. Acta, 40, 845 (1995).

17. C. Iwakura, M. Miyamoto, H. Inoue, M. Matsuoka, and Y. Fukumoto, J. Alloys and Compounds, 231, 558 (1995).

18. C. Iwakura, M. Miyamoto, H. Inoue, M. Matsuoka, and Y. Fukumoto, J. Electroanal. Chem., 411, 109 (1996).

19. H. Inoue, M. Miyamoto, M. Matsuoka, Y. Fukumoto, and C. Iwakura, Electrochim. Acta, 42, 1087 (1997).

20. H. Yang, Y. Zhang, Z. Zhou, J. Wei, G. Wang, D. Song, X. Cao. and C. Wang, J. Alloys and Compounds, 231, 625 (1995).

21. W. Zhang, M. P. . Kumar, and S. Srinivasan, and H. J. Ploehn, J. Electrochem. Soc., 142, 2936 (1995).

22. G. Zheng, B. N. Popov, and R. E. White, , J. Electrochem. Soc., 143, 435 (1996).

23. N. Cui, B. Luan, H. J. Zhao, H. K. Liu, and S. X. Dou, J. Alloys and Compounds, 248, 159 (1997).

24. B. Reichman, W. Mays, M. A. Fetcenko and S. R. Ovshinsky, in Electrochemical Surface Science of Hydrogen Adsorption and Absorption, G. Jerkiewicz and P. Marcus, Editors, , PV 97-16, p.236, The Electrochemical Society Proceedings Series, Pennington, NJ (1997).

25. L. O. Valoen, S. Sunde, and R. Tunold, J. Alloys and Compounds, 253-254, 656 (1997).

26. P. Millet and P. Dantzer, J. Alloys and Compounds, 253-254, 542 (1997).

27. W-K. Hu, H. Lee, D-M. Kim, S-W. Jeon, and J-Y. Lee, J. Alloys and Compounds, 268, 261 (1998).

28. C. Wang, J. Electrochem. Soc., 145, 1801 (1998).

29. W. T. Elam, J. P. Kirkland, R. A. Neiler and P. E. Wolf, Phys. Rev. B., 38, 26 (1988).

30. D. E. Sayer, D. A. Bunker, in X-ray Absorption: Principles, Aplications, Techniques of EXAFS, SEXAFS and XANES, D. C. Koningsberger and R. Prins (Eds.), John Wiley \& Sons, New York (1988).

31. S. Mukerjee, S. Srinivasan, M. P. Soriaga, and J. McBreen, J. Electrochem. Soc., 142, 1409 (1995).

32. S. Mukerjee, S. Srinivasan, M. P. Soriaga, and J. McBreen, J. Phys Chem., 99, 4577 (1995).

33. H. E. G. Rommal and P. J. Moran, J. Electrochem. Soc., 135, 343 (1988). 
Table 1 - Alloy characteristics and capacity decay on cycling, $Q_{\max }$ is the maximum capacity.

\begin{tabular}{lccccc}
\hline \multicolumn{1}{c}{ Alloy } & $\begin{array}{c}\mathrm{Q}_{\max } \\
\left(\mathrm{mAh} \mathrm{g}^{-1}\right)\end{array}$ & $\begin{array}{c}\mathrm{V}_{\mathrm{H}}{ }^{(*)} \\
\left(\AA^{3}\right)\end{array}$ & $\begin{array}{c}\mathrm{H} \text { atoms } / \\
\text { Unit cell }\end{array}$ & $\begin{array}{c}\text { Volume } \\
\text { Expansion }\end{array}$ & $\begin{array}{c}\text { Decay } \\
(\%)\end{array}$ \\
\hline $\mathrm{LaNi}_{4.7} \mathrm{Sn}_{0.3}$ & 308 & 3.26 & 5.05 & 18.4 & 0.22 \\
\hline $\mathrm{La}_{0.9} \mathrm{Y}_{0.1} \mathrm{Ni}_{4.7} \mathrm{Sn}_{0.3}$ & 287 & - & 4.71 & - & 0.16 \\
\hline $\mathrm{La}_{0.8} \mathrm{Y}_{0.2} \mathrm{Ni}_{4.7} \mathrm{Sn}_{0.3}$ & 268 & 3.11 & 4.36 & 15.4 & 0.10 \\
\hline $\mathrm{La}_{0.7} \mathrm{Y}_{0.3} \mathrm{Ni}_{4.7} \mathrm{Sn}_{0.3}$ & 198 & - & - & - & $\sim 0.16$ \\
\hline $\mathrm{La}_{0.7} \mathrm{Y}_{0.3} \mathrm{Ni}_{4.6} \mathrm{Sn}_{0.3} \mathrm{Co}_{0.1}$ & 221 & - & - & - & $\sim 0.10$
\end{tabular}

$\left({ }^{*}\right)$ Atomic volume of $\mathrm{H}$ in the hydride phase; $\left({ }^{* *}\right)$ Expansion of unit cell in charge cycle

Table 2 - Electrode kinetic parameters, exchange current $j_{0}$ and activation energy obtained from galvanodynamic measurements.

Hydrogen oxidation reaction - SOC $100 \%$

\begin{tabular}{|c|c|c|}
\hline Alloy & $\begin{array}{c}\mathrm{j}_{0} \text { at } 25^{\circ} \mathrm{C} \\
\left(\mathrm{mA} \mathrm{g}^{-1}\right)\end{array}$ & $\begin{array}{l}\text { Activation Energy } \\
\left(\mathrm{kJ} \mathrm{mol}^{-1}\right)\end{array}$ \\
\hline $\begin{array}{c}\mathrm{LaNi}_{4.7} \mathrm{Sn}_{0.3}-\text { activated }(8 \text { cycles }) \\
-130 \text { cycles }\end{array}$ & $\begin{array}{c}88 \\
194\end{array}$ & 34 \\
\hline $\mathrm{La}_{0.9} \mathrm{Y}_{0.1} \mathrm{Ni}_{4.7} \mathrm{Sn}_{0.3} 3$ - activated ( 20 cycles) & 53 & 35 \\
\hline $\begin{array}{c}\mathrm{La}_{0.8} \mathrm{Y}_{0.2} \mathrm{Ni}_{4.7} \mathrm{Sn}_{0.3}-\text { activated }(20 \text { cycles }) \\
-130 \text { cycles }\end{array}$ & $\begin{array}{c}52 \\
148\end{array}$ & 35 \\
\hline $\mathrm{La}_{0.7} \mathrm{Y}_{0.3} \mathrm{Ni}_{4.7} \mathrm{Sn}_{0.3}-$ activated $(20$ cycles $)$ & 52 & 30 \\
\hline $\mathrm{La}_{0.7} \mathrm{Y}_{0.3} \mathrm{Ni}_{4.6} \mathrm{Sn}_{0.3} \mathrm{Co}_{0.1}$ - activated (22 cycles) & 41 & 32 \\
\hline \multicolumn{3}{|l|}{ Hydrogen evolution reaction } \\
\hline Alloy & $\begin{array}{c}\mathrm{j}_{0} \text { at } 25^{\circ} \mathrm{C} \\
\left.(\mathrm{mA} \mathrm{g})^{-1}\right)\end{array}$ & $\begin{array}{l}\text { Activation Energy } \\
\left(\mathrm{kJ} \mathrm{mol}^{-1}\right)\end{array}$ \\
\hline $\begin{array}{c}\mathrm{LaNi}_{4.7} \mathrm{Sn}_{0.3}-\text { activated }(8 \text { cycles }) \\
-130 \text { cycles }\end{array}$ & $\begin{array}{l}103 \\
227\end{array}$ & 34 \\
\hline $\mathrm{La}_{0.9} \mathrm{Y}_{0.1} \mathrm{Ni}_{4.7} \mathrm{Sn}_{0.3}-$ activated $(20$ cycles $)$ & 55 & 40 \\
\hline $\begin{array}{c}\mathrm{La}_{0.8} \mathrm{Y}_{0.2} \mathrm{Ni}_{4.7} \mathrm{Sn}_{0.3}-\text { activated }(20 \text { cycles }) \\
-130 \text { cycles }\end{array}$ & $\begin{array}{c}58 \\
164 \\
\end{array}$ & 43 \\
\hline $\mathrm{La}_{0.7} \mathrm{Y}_{0.3} \mathrm{Ni}_{4.7} \mathrm{Sn}_{0.3}-$ activated $(20$ cycles $)$ & 54 & 40 \\
\hline $\mathrm{La}_{0.7} \mathrm{Y}_{0.3} \mathrm{Ni}_{4.6} \mathrm{Sn}_{0.3} \mathrm{Co}_{0.1}-$ activated $(22$ cycles $)$ & 43 & 38 \\
\hline
\end{tabular}


Table 3 - Summary of kinetic from EIS at various SOC.

\begin{tabular}{|c|cc|cc|}
\hline SOC & \multicolumn{2}{|c|}{$\mathrm{LaNi}_{4.7} \mathrm{Sn}_{0.3}$-activated (8 cycles) } & $\mathrm{La}_{0.8} \mathrm{Y}_{0.2} \mathrm{Ni}_{4.7} \mathrm{Sn}_{0.3}$ - activated (20 cycles) \\
\hline $\begin{array}{c}\mathrm{j}_{\mathrm{o}} \text { at } 25^{\circ} \mathrm{C} \\
\left(\mathrm{mA} \mathrm{g}^{-1}\right)\end{array}$ & $\begin{array}{c}\mathrm{E}_{\mathrm{a}} \\
\left(\mathrm{kJ} \mathrm{mol}^{-1}\right)\end{array}$ & $\begin{array}{c}\mathrm{j}_{\mathrm{o}} \text { at } 25^{\circ} \mathrm{C} \\
\left(\mathrm{mA} \mathrm{g}^{-1}\right)\end{array}$ & $\begin{array}{c}\mathrm{E}_{\mathrm{a}} \\
\left(\mathrm{kJ} \mathrm{mol}^{-1}\right)\end{array}$ \\
\hline $75 \%$ & 87 & 32 & 58 & 39 \\
$50 \%$ & 88 & 36 & 79 & 38 \\
$23 \%$ & 97 & 36 & 116 & 39 \\
\hline
\end{tabular}
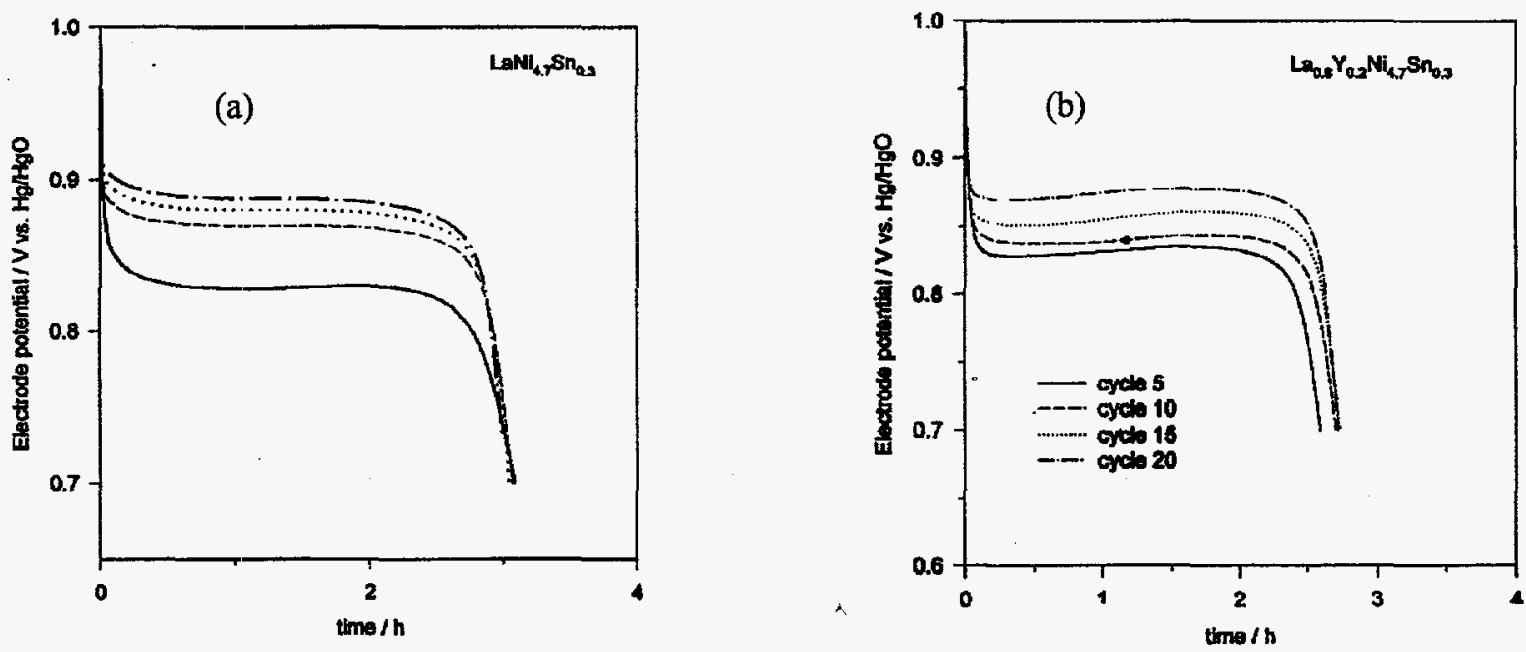

Fig. 1. Discharge curves for (a) $\mathrm{LaB}_{5}$ and (b) $\mathrm{La}_{0.8} \mathrm{Y}_{0.2} \mathrm{~B}_{5}$ alloys $\left(\mathrm{B}_{5}=\mathrm{Ni}_{4.7} \mathrm{Sn}_{0.3}\right)$ after, $5,10,15$ and 20 charge/discharge cycles, discharge rate $100 \mathrm{mAg}^{-1}(\mathrm{C} / 3)$.

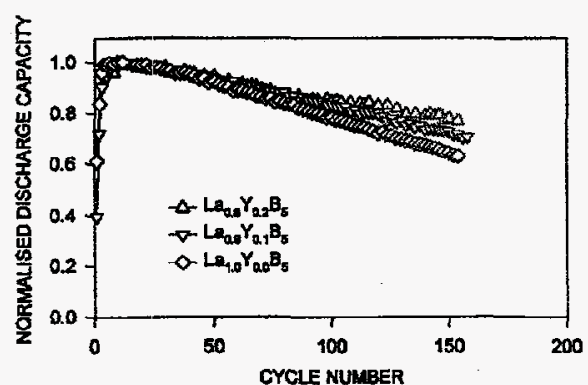

Fig. 2. Normalized capacity/cycle life data for alloys. charged at $C / 3$ rate for $4 \mathrm{~h}$, diacharged at $\mathrm{C} / 3$ to $0.7 \mathrm{~V}$ vs. $\mathrm{Hg} / \mathrm{HgO} . \mathrm{B}=\mathrm{Ni}_{4.7} \mathrm{Sn}_{0.3}$.

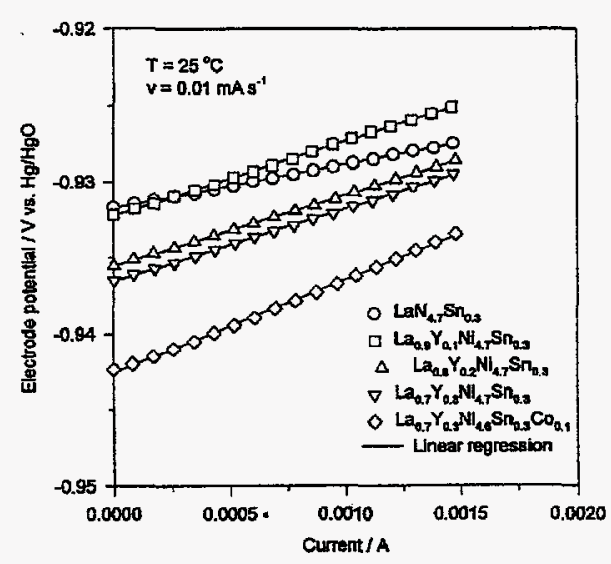

Fig. 3. Galvanodynamic sweeps for alloy electrodes. Sweep rate $0.01 \mathrm{mAs}^{-1}$. 

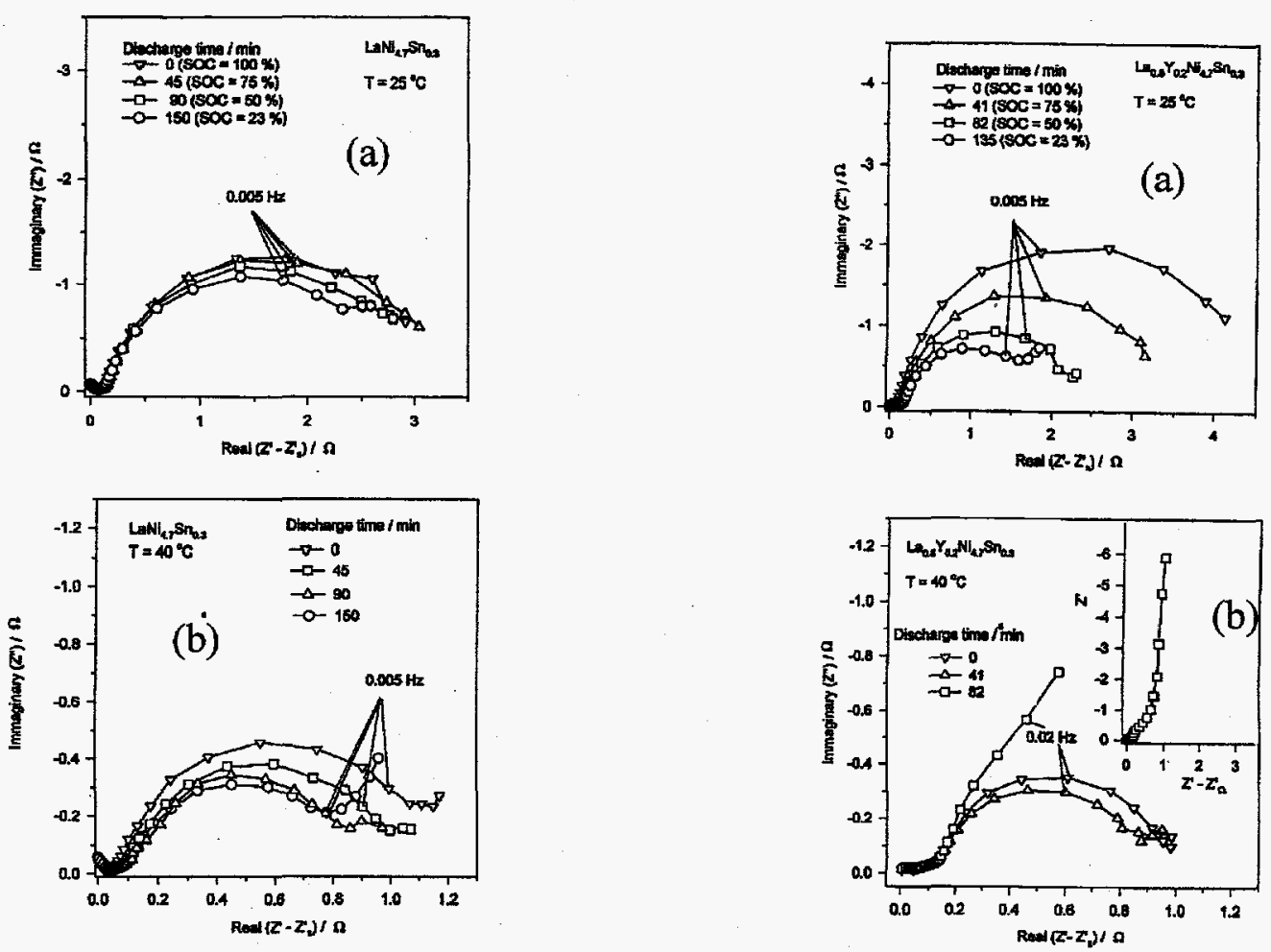

Fig. 4. Nyquist plots for $\mathrm{LaB}_{5}$ at various $\mathrm{SOC}$; (a) $25^{\circ} \mathrm{C}$, (b) $40^{\circ} \mathrm{C}, 10 \mathrm{kHz}$ to 0.001 $\mathrm{Hz}$. Real part corrected for ohmic drop.
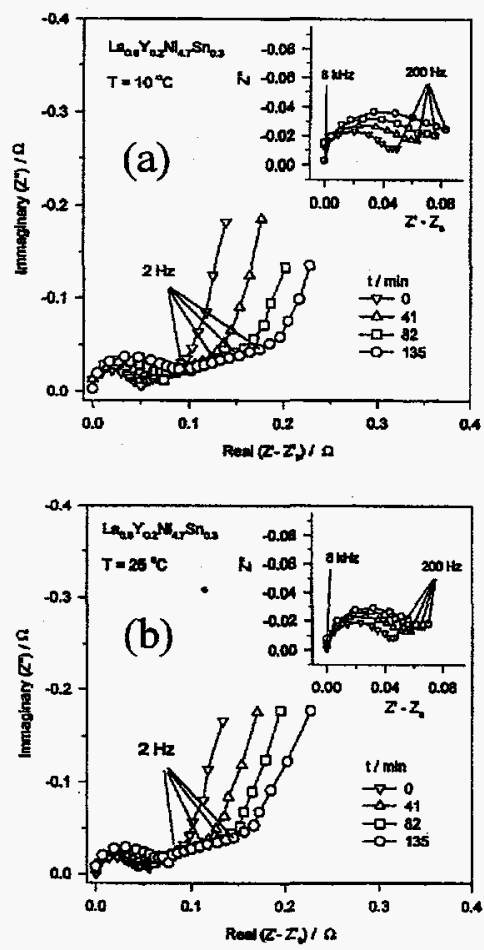

Fig. 6. Nyquist plots for $\mathrm{La}_{0.8} \mathrm{Y}_{0.2} \mathrm{~B}_{5}$ at high frequencies;

(a) $10^{\circ} \mathrm{C}$, (b) $25^{\circ} \mathrm{C}$
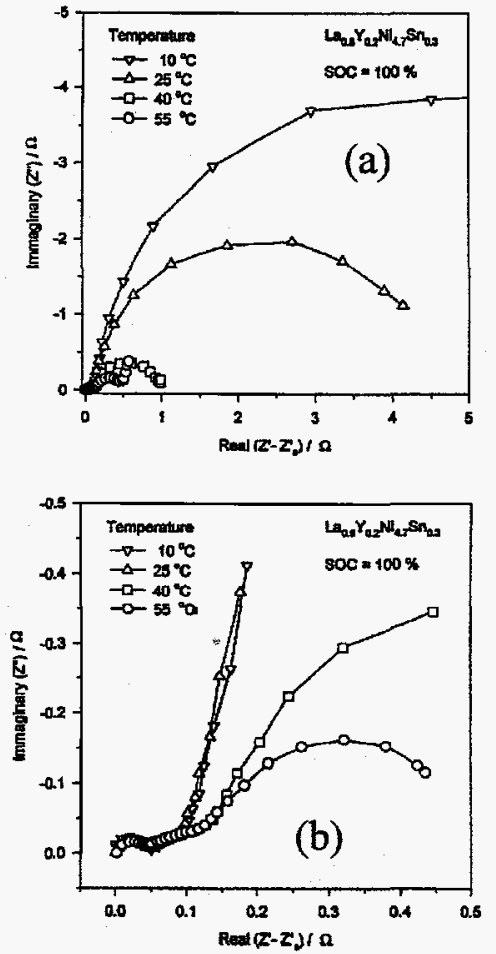

Fig. 7. Effect of temperature on Nyquist plots for $\mathrm{La}_{0.8} \mathrm{Y}_{0.2} \mathrm{~B}_{5}$ at $100 \%$ SOC. 


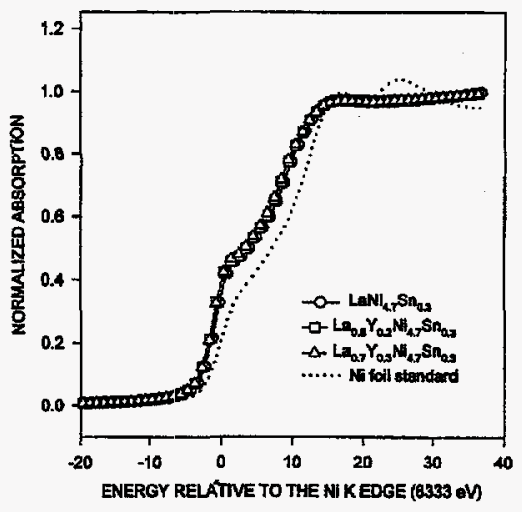

Fig. 8. Ni XANES for $\mathrm{Ni}$ foil and uncycled gas activated alloys transmission mode.

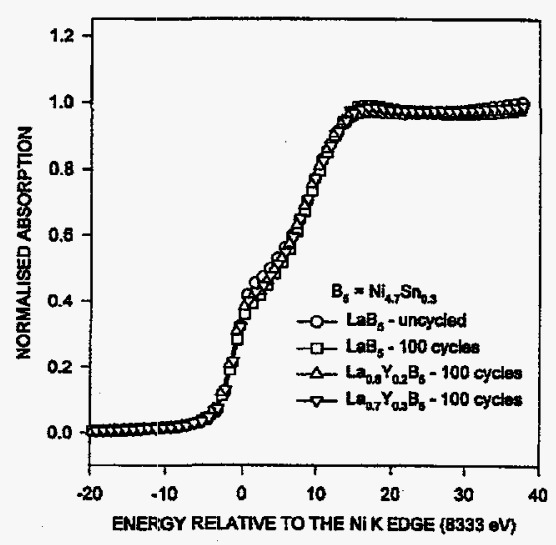

Fig. 10. Ni XANES for cycled alloy, 100 cycles, transmission mode.

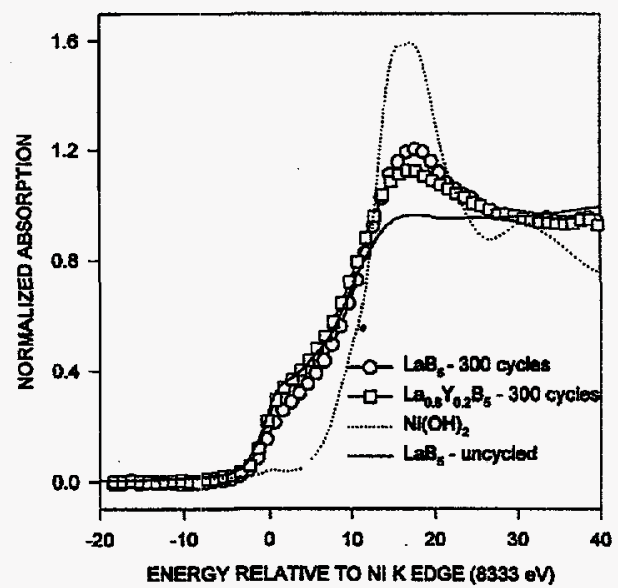

Fig. 12. Ni XANES for cycled alloy, 300 cycles, electron yield mode. XANES for $\mathrm{Ni}(\mathrm{OH})_{2}$ transmission mode.

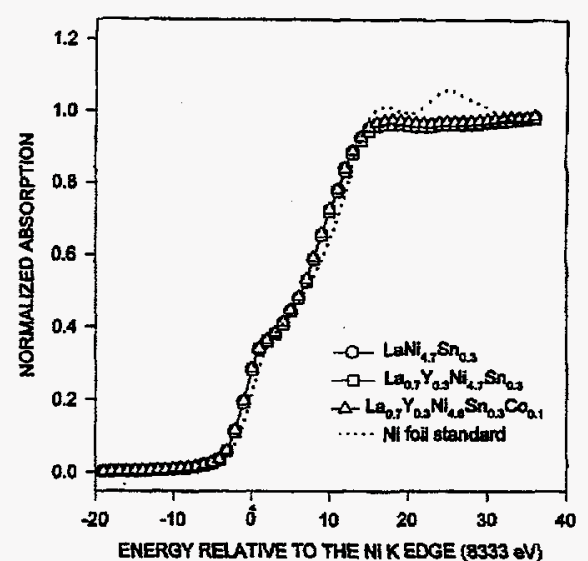

Fig. 9. Ni XANES for Ni foil and uncycled alloy, electron yield mode.

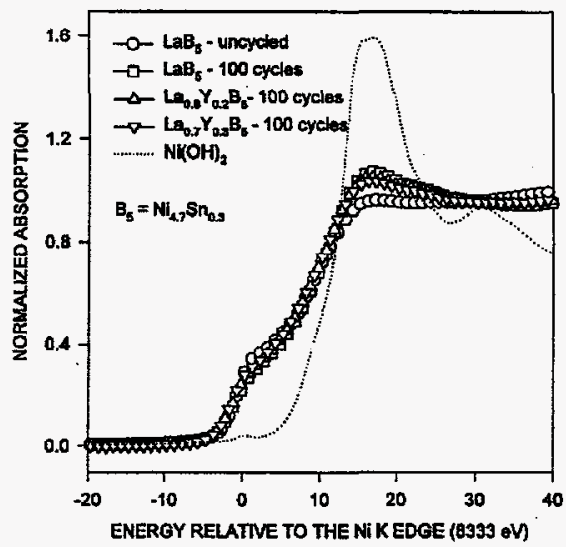

Fig. 11. Ni XANES for cycled alloy, 100 cycles, electron yield mode. XANES for $\mathrm{Ni}(\mathrm{OH})_{2}$ transmission mode.

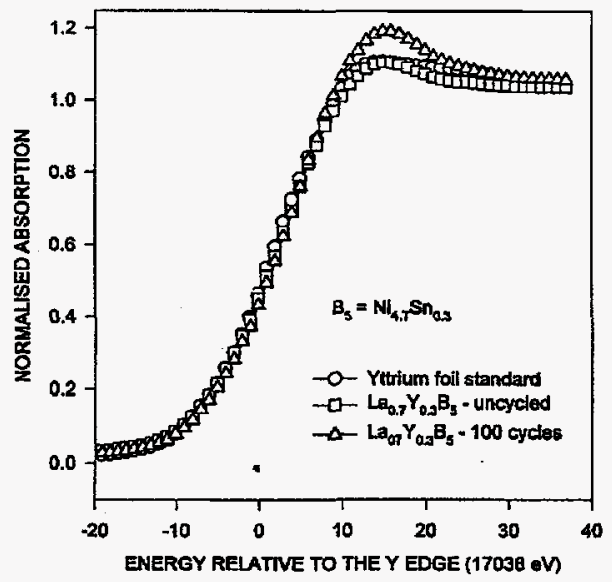

Fig. 13. Y XANES for $Y$ foil, uncycled alloy, and alloy and after 100 cycles, transmission mode. 